\title{
SELECTIVE LOSS OF ACETYLCHOLINE SENSITIVITY IN A NERVE CELL LINE CULTURED IN HORMONE-SUPPLEMENTED SERUM-FREE MEDIUM ${ }^{1}$
}

\author{
MASAYUKI MITSUKA ${ }^{2}$ AND HIROSHI HATANAKA ${ }^{3}$ \\ Department of Neuroscience, Mitsubishi-Kasei Institute of Life Sciences, 11 Minamiooya, Machida-shi, Tokyo 194, Japan
}

Received January 5, 1983; Revised March 28, 1983; Accepted March 31, 1983

\begin{abstract}
When clonal rat pheochromocytoma PC12h cells were cultured in a hormone-supplemented serum-free medium, the carbamylcholine-elicited catecholamine release from cells cultured in serumfree medium was completely abolished. On the other hand, the high potassium-induced catecholamine release was not changed, even in $\mathrm{PC} 12 \mathrm{~h}$ cells cultured in serum-free medium. The lack of carbamylcholine sensitivity was confirmed directly by measuring carbamylcholine-induced ${ }^{22} \mathrm{Na}$ influx, which was completely abolished in PC12h cells cultured in serum-free medium. The loss of carbamylcholine-induced ${ }^{22} \mathrm{Na}$ influx seemed to obey nearly first-order kinetics and was fully restored upon a re-exposure to serum. The half-time for the loss was about 1 day, and the cultivation for 5 days in serum-free medium caused a $95 \%$ decrease of the nicotinic sensitivity in PC12h cells. The carbamylcholine-induced ${ }^{45} \mathrm{Ca}$ influx into cells also was lost due to the serum-free cultivation. By contrast, the binding of $\alpha$-bungarotoxin, which is an antagonist of nicotinic acetylcholine receptor in muscular cells, remained and did not change in PC12h cclls cultured, even in the serumfree medium. In addition, veratridine-dependent ${ }^{22} \mathrm{Na}$ influx and high potassium-induced ${ }^{45} \mathrm{Ca}$ influx into cells, and high potassium-induced ${ }^{86} \mathrm{Rb}$ efflux from cells cultured in the serum-free medium were also perfectly preserved. These results suggest that $\mathrm{PC} 12 \mathrm{~h}$ cells cultured in serum-free medium seemed to be a useful model for comparing the differential mechanisms between acetylcholine sensitivity and other membranous functions on this cell.
\end{abstract}

Many cell lines have been adapted to proliferate in a hormone-supplemented serum-free medium in the past few years (Barnes and Sato, 1980). There are many advantages to using this culture medium. For example, by cultivating the cells in serum-free medium, it is possible to avoid the effect of unknown substances that existed in serum, when one investigates the differential mechanisms of various cell functions. Thereafter, the difference of some cellular properties has been shown between the cells cultured in serum-free medium and

\footnotetext{
${ }^{1}$ We thank Drs. Y. Arimatsu, A. Ogura, and M. Takahashi for their valuable suggestions and discussions, and Drs. T. Amano and Y. Kudo for their encouragement during the work. This work was carried out in partial fulfillment of the requirements by M. M. for the degree of Doctor of Pharmaceutics in the Department of Pharmaceutical Sciences, University of Tokyo. M. M. is deeply indebted to Prof. H. Shimizu of the University of Tokyo for his helpful discussion.

${ }^{2}$ On leave from Department of Pharmaceutical Sciences, University of Tokyo, 7-3-1 Hongo, Bunkyo-ku, Tokyo 113, Japan. Present address: Central Research Laboratories, Mitsubishi Chemical Industries Limited, Yokohama, Kanagawa 227, Japan.

${ }^{3}$ To whom correspondence should be addressed.
}

those cultured in serum-containing medium (Darmon et al., 1981; Messer, 1981).

The PC12 cell, a cell line from rat pheochromocytoma, shows a variety of neuronal properties resembling those of sympathetic adrenergic neurons in response to nerve growth factor and is considered a useful model for studying differentiation of neural crest derivatives at cellular and molecular levels (Greene and Tischler, 1976; Greene and Shooter, 1980). The PC12 cell has nicotinic reactivity to acetylcholine as well as $\alpha$-bungarotoxin-binding sites, and is also considered a useful model for studying the neuronal nicotinic acetylcholine receptor (Patrick and Stallcup, 1977). Furthermore, muscarinic acetylcholine (ACh) receptors (Jumblatt and Tischler, 1982) and enkephalin receptors (Inoue and Hatanaka, 1982) were recently found in PC12 and PC12h cells, respectively.

In this report, we investigate the nicotinic acetylcholine reactivity of $\mathrm{PC} 12 \mathrm{~h}$ cells (a subclone of $\mathrm{PC} 12$ cells) cultured in serum-free medium. PC12h cells (Hatanaka, 1981) can grow in a hormone-supplemented serum-free medium, based on the method of Bottenstein and Sato (1979). When serum was omitted from culture medium, 
acetylcholine sensitivity was selectively and reversibly abolished, while $\alpha$-bungarotoxin binding remained and did not change.

\section{Materials and Methods}

Cells. PC12h cells (a subclone of PC12 cells) were used throughout the present study. These cells were usually maintained in a glass culture flask using Dulbecco's modified Eagle's (DME) medium supplemented with $5 \%$ $(\mathrm{v} / \mathrm{v})$ heat-inactivated horse serum (GIBCO) and $5 \%(\mathrm{v} /$ v) precolostrum newborn calf serum (Mitsubishi-Kasei Nakashibetsu Serum Center). For the serum-free cultivation, TIP/DF medium (Hatanaka, 1981, 1983) was developed, based on the method of Bottenstein and Sato (1979), consisting of a 1:1 mixture DME medium and Ham's F12 medium (GIBCO) supplemented with $1.9 \mathrm{mg} /$ $\mathrm{ml}$ of sodium bicarbonate, $15 \mathrm{mM}$ HEPES buffer, 50 units $/ \mathrm{ml}$ of penicillin, $100 \mu \mathrm{g} / \mathrm{ml}$ of streptomycin, $30 \mathrm{mM}$ selenium, $5 \mu \mathrm{g} / \mathrm{ml}$ of human transferrin, $5 \mu \mathrm{g} / \mathrm{ml}$ of bovine insulin, and $20 \mathrm{nM}$ progesterone. In this culture condition, $\mathrm{PC} 12 \mathrm{~h}$ cells have almost the same rate of cell proliferation and cellular protein synthesis, as well as nerve growth factor-elicited neurite formation, as cells cultured in serum-containing medium (Hatanaka et al., 1982; Hatanaka, 1983).

Assay of catecholamine release. Release of $\left[{ }^{3} \mathrm{H}\right]$ norepinephrine from PC12h cells was measured as previously reported (Greene and Rein, 1977), with the modification of Takahashi et al. (1982). PC12h cells were incubated with HEPES-buffered Krebs' modified Ringer (KRH) solution, which consisted of $50 \mathrm{~mm}$ HEPES buffer $(\mathrm{pH}$ 7.4), $130 \mathrm{mM} \mathrm{NaCl}, 5.4 \mathrm{mM} \mathrm{KCl}, 1.8 \mathrm{mM} \mathrm{CaCl}_{2}, 0.8 \mathrm{~mm}$ $\mathrm{MgSO}_{4}, 5.5 \mathrm{mM}$ glucose, and $1 \mathrm{mM} \mathrm{NaH} \mathrm{PO}_{4}$, containing $0.25 \mu \mathrm{Ci}$ of $\left[{ }^{3} \mathrm{H}\right]$ norepinephrine and $1.1 \mathrm{mM}$ L-ascorbic acid, for $60 \mathrm{~min}$. After washing the cells, the release of preloaded $\left[{ }^{3} \mathrm{H}\right]$ norepinephrine into the medium was measured by changing the medium successively for 1min intervals. The release was expressed as percentage of remaining radioactivity in the cells. Values are the mean of the assay using duplicate dishes. In order to measure the carbamylcholine- and voltage-dependent $\left[{ }^{3} \mathrm{H}\right]$ norepinephrine release, $0.4 \mathrm{mM}$ carbamylcholine was added and the concentration of $\mathrm{KCl}$ was raised to 51.4 $\mathrm{mM}$, respectively.

Assay of sodium influx. Assay of carbamylcholine- and voltage-dependent ${ }^{22} \mathrm{Na}$ influx into cells was performed by the method of Stallcup (1979). PC12h cells cultured in serum-containing medium were replated on polylysine-coated $35-\mathrm{mm}$ Falcon dishes at a density of $10^{5}$ cells $/ \mathrm{cm}^{2}$. After overnight culture, medium was changed to TIP/DF medium for the experiments using the serumfree medium. The assay of carbamylcholine-dependent ${ }^{22} \mathrm{Na}$ influx was done as follows. Cells were washed once with $\mathrm{KRH}$ solution. ${ }^{22} \mathrm{Na}$ uptake into cells was carried out at $20^{\circ} \mathrm{C}$ in $\mathrm{KRH}$ solution (total volume, $0.5 \mathrm{ml}$ ) containing $1 \mu \mathrm{Ci}$ of ${ }^{22} \mathrm{Na}$ and $5 \mathrm{mM}$ ouabain, with or without $5 \mathrm{~mm}$ carbamylcholine. For the assay of voltagedependent ${ }^{22} \mathrm{Na}$ influx, PC12h cells were pre-incubated at $37^{\circ} \mathrm{C}$ with the $\mathrm{Ca}$-free $\mathrm{KRH}$ solution containing 10 $\mu \mathrm{g} / \mathrm{ml}$ of scorpion toxin. ${ }^{22} \mathrm{Na}$ uptake into cells was measured at $37^{\circ} \mathrm{C}$ in calcium-free $\mathrm{KRH}$ solution (total volume, $0.5 \mathrm{ml}$ ) containing $1 \mu \mathrm{Ci}$ of ${ }^{22} \mathrm{Na}, 5 \mathrm{~mm}$ ouabain, and $10 \mu \mathrm{g} / \mathrm{ml}$ of scorpion toxin, with or without $0.2 \mathrm{mM}$ veratridine. Reactions were stopped by washing with icecold KRH solution five times, and cells were scraped and the radioactivity into cells was counted by a Beckmann gamma counter. Protein concentration of the cells was determined by the method of Lowry et al. (1951) with bovine serum albumin as the standard.

Assay of calcium influx. Carbamylcholine- and voltagedependent ${ }^{45} \mathrm{Ca}$ influx were also performed by the method of Stallcup (1979) with the modification of Takahashi et al. (1982). The assay of carbamylcholine-dependent ${ }^{45} \mathrm{Ca}$ influx into cells was done as follows. Assay was carried out at $37^{\circ} \mathrm{C}$ in sodium- and phosphate-free $\mathrm{KRH}$ solution (total volume, $0.5 \mathrm{ml}$ ) containing $260 \mathrm{mM}$ sucrose, $10 \mu \mathrm{Ci}$ of ${ }^{45} \mathrm{Ca}$, and $2 \mathrm{~mm} \mathrm{MnCl}_{2}$ with $2 \mathrm{mM}$ carbamylcholine. Nonspecific influx was controlled by adding $10 \mathrm{mM} d$ tubocurarine in assay medium. The assay of voltagedependent ${ }^{45} \mathrm{Ca}$ influx was carried out at $37^{\circ} \mathrm{C}$. Assay solution was sodium- and phosphate-free $\mathrm{KRH}$ solution containing $260 \mathrm{mM}$ sucrose and $2 \mu \mathrm{Ci}$ of ${ }^{45} \mathrm{Ca}$ with 5.4 $\mathrm{mM}$ or $51.4 \mathrm{~mm} \mathrm{KCl}$.

Assay of rubidium efflux. Activation of potassium channel in PC12h cells was studied by the method of Arner and Stallcup (1981), comparing ${ }^{86} \mathrm{Rb}$ efflux under depolarizing and nondepolarizing conditions. $\mathrm{PC} 12 \mathrm{~h}$ cells were pre-incubated in phosphate-free KRH solution containing $10 \mu \mathrm{Ci}$ of ${ }^{86} \mathrm{Rb}$ and $2 \mathrm{mM}$ ouabain for $60 \mathrm{~min}$ at $37^{\circ} \mathrm{C}$. Then, cells were washed and the activation of ${ }^{86} \mathrm{Rb}$ release by $51.4 \mathrm{mM} \mathrm{KCl}$ was carried out at $37^{\circ} \mathrm{C}$. For measuring efflux, $100-\mu \mathrm{l}$ aliquots were taken over during the course of several minutes for counting of the radioactivity in medium. After the reaction, the radioactivity remaining in the cells was also measured.

Binding assay of $\left[{ }^{125} I\right] \alpha$-bungarotoxin. $\alpha$-Bungarotoxin $(\alpha-\mathrm{BGT})$ was purified from the venom of Bungarus multicinctus and iodinated with ${ }^{125} \mathrm{I}$ by the chloramine $\mathrm{T}$ method of Hunter and Greenwood (1962), with modification of Seto et al. (1977). PC12h cells were incubated with KRH solution containing $10 \mathrm{nM}\left[{ }^{125} \mathrm{I}\right] \alpha$-BGT for 30 min at $20^{\circ} \mathrm{C}$. Then, cells were washed and scraped with $\mathrm{KRH}$ solution. The radioactivity was counted by a gamma counter. Nonspecific binding was estimated by pretreatment with $5 \mu \mathrm{M}$ unlabeled $\alpha$-BGT prior to binding assay. The $\left[{ }^{125} \mathrm{I}\right] \alpha$-BGT binding was also reduced by $d$-tubocurarine in a dose-dependent manner.

Materials. ${ }^{22} \mathrm{Na},{ }^{86} \mathrm{Rb},{ }^{125} \mathrm{I}$, and $\left[{ }^{3} \mathrm{H}\right]$ norepinephrine were obtained from New England Nuclear, and ${ }^{45} \mathrm{Ca}$ was obtained from Amersham. Human transferrin, poly-Dlysine, HEPES, carbamylcholine, veratridine, ouabain, and venom scorpion of Tityus serrulatus were purchased from Sigma Chemical Co., bovine insulin came from Colaboratory Research Inc.; venom of Bungarus multicinctus was from Miami Serpentarium Laboratory; penicillin G was from Meiji Seika Co., and streptomycin sulfate was from Kyowa Hakko Co. Nerve growth factor (2.5 $\mathrm{S}$ form) was prepared from male mouse salivary gland by the method of Bocchini and Angeletti (1969) with minor modification of Suda et al. (1978).

\section{Results}

PC12h cells cultured in TIP/DF medium have already been reported to have a tyrosine hydroxylase activity 
which is selectively induced by nerve growth factor (Hatanaka, 1981, 1983). The high potassium- and carbamylcholine-elicited release of cellular catecholamine in PC12h cells cultured in TIP/DF medium was examined. The preloaded $\left[{ }^{3} \mathrm{H}\right]$ norepinephrine in $\mathrm{PC} 12 \mathrm{~h}$ cells cultured in TIP/DF medium was released by transferring the cells to high potassium medium, as shown in Figure 1 , whereas exposure of these cells to $0.4 \mathrm{mM}$ carbamylcholine failed to result in the release of $\left[{ }^{3} \mathrm{H}\right]$ norepinephrine. As shown in Figure 1, PC12h cells cultured in serum-containing medium have both releasing mechanisms elicited by the exposure to high potassium concentration and carbamylcholine. These results indicate that PC12h cells cultured in TIP/DF medium retained a voltage-dependent releasing mechanism but lost tine carbamylcholine sensitivity.

The carbamylcholine response to $\mathrm{PC} 12$ cells is known to be nicotinic (Greene and Rein, 1977). Therefore, we examined the following two responses for nicotinic $\mathrm{ACh}$ receptor: one was carbamylcholine-clicited ${ }^{22} \mathrm{Na}$ and ${ }^{45} \mathrm{Ca}$

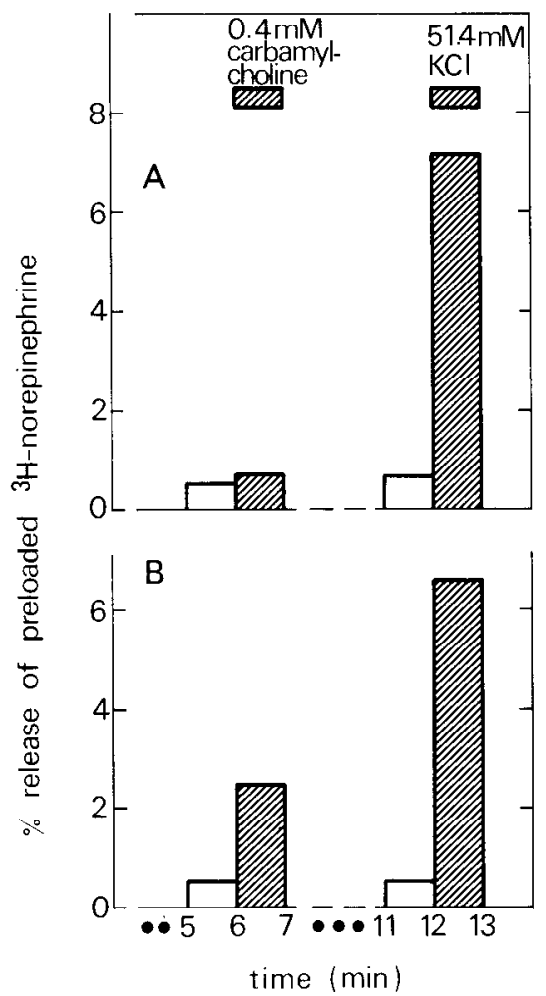

Figure 1. Release of preloaded $\left[{ }^{3} \mathrm{H}\right]$ norepinephrine from PC12h cells cultured in TIP/DF medium $(A)$ and serumcontaining medium $(B)$. Cells were plated on collagen-coated $35-\mathrm{mm}$ dishes at a density of $1.5 \times 10^{5}$ cells $/ \mathrm{cm}^{2}$ in serumcontaining medium. After the overnight culture, the medium was changed to TIP/DF medium $(A)$ or serum-containing medium $(B)$. Culture was continued for 4 more days. The preloaded $\left[{ }^{3} \mathrm{H}\right]$ norepinephrine was released by transfer to the medium containing high $\mathrm{KCl}(51.4 \mathrm{mM})$ or carbamylcholine $(0.4 \mathrm{~mm})$, as described in detail in the text. The release of $\left[{ }^{3} \mathrm{H}\right]$ norepinephrine is expressed as a percentage of remaining $\left[{ }^{3} \mathrm{H}\right]$ norepinephrine in the cells at the end of each period. The total counts of $\left[{ }^{3} \mathrm{H}\right]$ norepinephrine uptake into the cells cultured in serum-containing medium and TIP/DF medium were $3.86 \times$ $10^{4}$ and $4.01 \times 10^{4} \mathrm{cpm} / \mathrm{dish}$, respectively. Values were the mean of duplicate cultures.

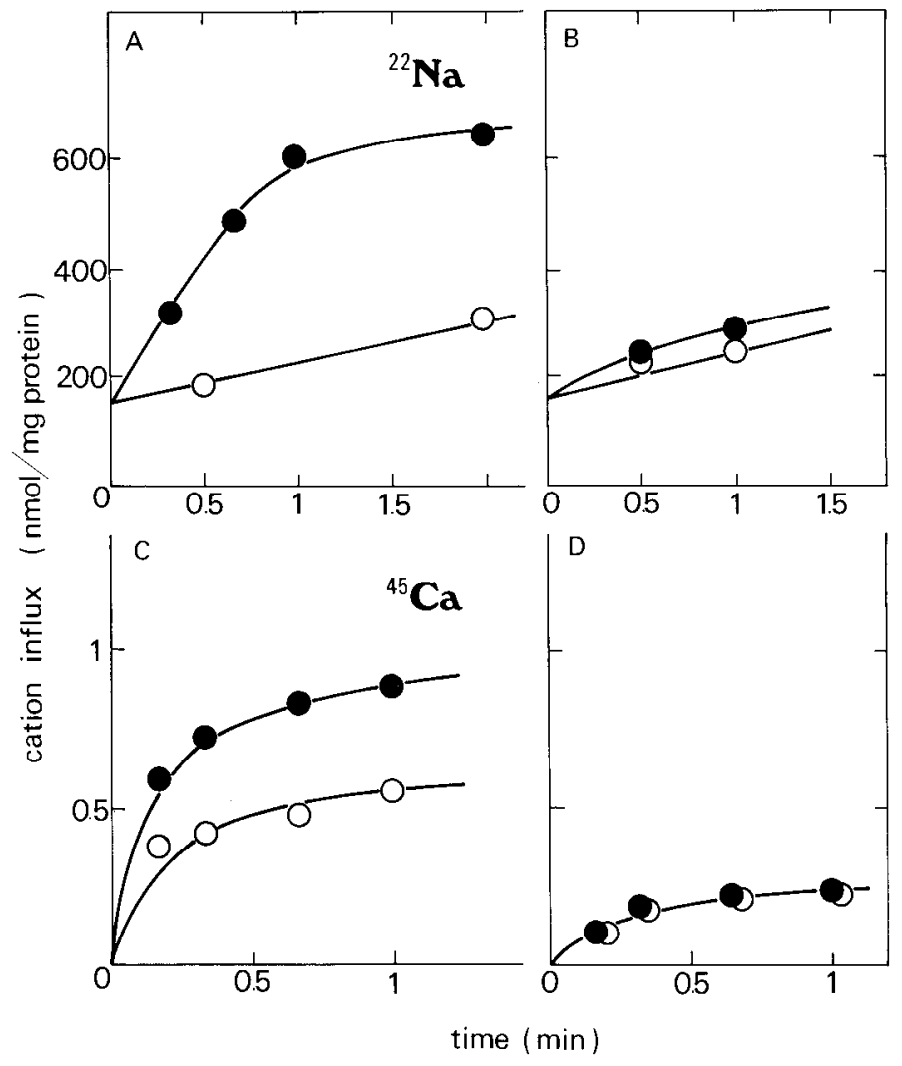

Figure 2. Carbamylcholine-induced ${ }^{22} \mathrm{Na}$ and ${ }^{45} \mathrm{Ca}$ ion influx into PC12h cells cultured in serum-containing medium ( $A$ and $C$ ) and TIP/DF medium ( $B$ and $D)$. At time zero, media were changed to those containing ${ }^{22} \mathrm{Na}$ or ${ }^{45} \mathrm{Ca}$ ion. For ${ }^{22} \mathrm{Na}$ ion influx ( $A$ and $B$ ), carbamylcholine response was measured by the addition of $5 \mathrm{mM}$ carbamylcholine $(1)$ in comparison with no addition $(O)$. For ${ }^{45} \mathrm{Ca}$ ion influx $(C$ and $D)$, cells were depolarized by the addition of $2 \mathrm{mM}$ carbamylcholine (O). Nonspecific ${ }^{45} \mathrm{Ca}$ ion uptake was measured in the presence of $10 \mathrm{mM} d$-tubocurarine (O).

ion influx into cells and the other was $\left[{ }^{125} \mathrm{I}\right] \alpha$-BGT binding on cell membrane. $\alpha$-BGT is thought to be a specific antagonist for nicotinic $\mathrm{ACh}$ receptor in mammalian muscle cells. Both carbamylcholine-elicited ${ }^{22} \mathrm{Na}$ ion influx (Fig. $2 B$ ) and ${ }^{45} \mathrm{Ca}$ ion influx (Fig. $2 D$ ) were completely lost by cultivating the cells in TIP/DF medium. Control cells which were cultured in the serum-containing medium had significant carbamylcholine responses, as shown in Figure $2, A$ and $C$. Figure $3 B$ shows the time course of the loss of carbamylcholine-elicited ${ }^{22} \mathrm{Na}$ ion influx into cells during cultivation in TIP/DF medium. The rate of influx was determined by the amount of ${ }^{22} \mathrm{Na}$ ion in cells, $0.5 \mathrm{~min}$ after exposure to carbamylcholine. The carbamylcholine response to cells was gradually decreased by cultivating in TIP/DF medium. The loss seems to obey nearly first-order kinetics. As can be seen in Figure $3 B$, the half-time for the loss was about 1 day. On the other hand, the $\left[{ }^{125} \mathrm{I}\right] \alpha$-BGT binding on cell membrane was stable during cultivation of the cells in TIP/DF medium (Fig. 3A). These results strongly support the difference of the $\alpha$-BGT-binding molecule from the functional $\mathrm{ACh}$ receptor in PC12 cells as previously described by Patrick and Stallcup (1977). Figure 3 also shows that the temporary loss of the carbamylcholine 

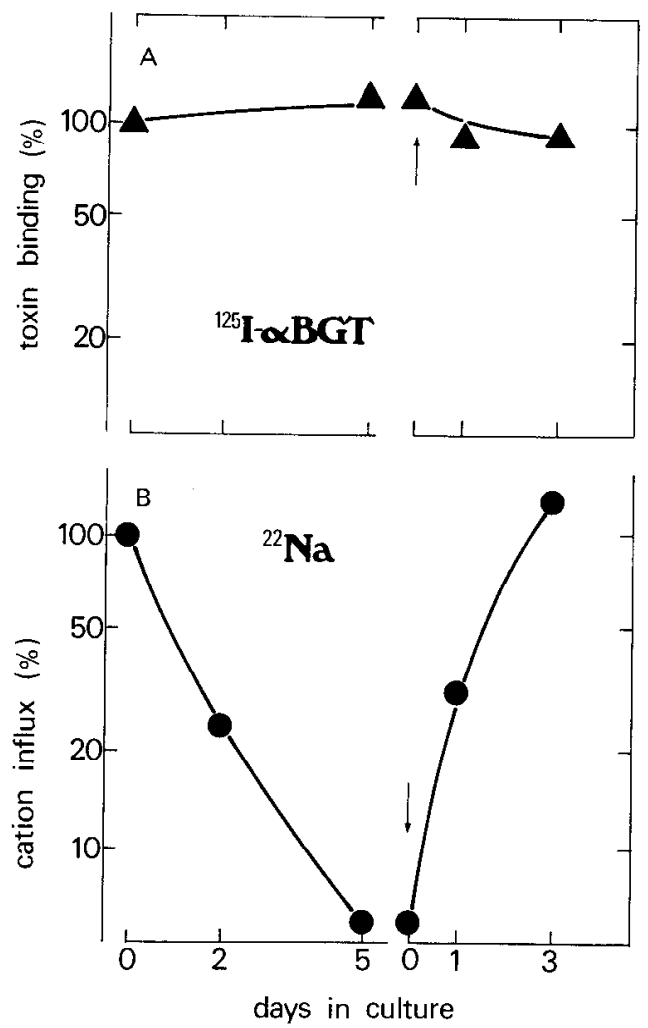

Figure 3. The time dependency on culture condition of $\mathrm{PC} 12 \mathrm{~h}$ cells for the carbamylcholine-induced ${ }^{22} \mathrm{Na}$ ion influx (O) into cells and $\left[{ }^{125} \mathrm{I}\right] \alpha$-BGT binding $(\boldsymbol{\Delta})$ to cell membranes. $\mathrm{PC} 12 \mathrm{~h}$ cells were plated on the poly-D-lysine-coated $35-\mathrm{mm}$ culture dishes at a density of $8 \times 10^{4} \mathrm{cclls} / \mathrm{cm}^{2}$ with the serumcontaining medium. The next day, ${ }^{22} \mathrm{Na}$ ion influx and $\left[{ }^{125} \mathrm{I}\right] \alpha-$ BGT binding were measured. At the same time the media of remaining sister cultures were changed to TIP/DF medium. After 2 to 5 days, the ability of ${ }^{22} \mathrm{Na}$ ion influx and $\left[{ }^{125} \mathrm{I}\right] \alpha$-BGT binding were measured, and then were expressed as percentage of the values at day 0 . PC12h cells cultured in TIP/DF medium for 5 days were then replated on new dishes with the serumcontaining medium. The ability of ${ }^{22} \mathrm{Na}$ ion influx and $\left[{ }^{125} \mathrm{I}\right] \alpha$ BGT binding were followed. The assay of carbamylcholineinduced ${ }^{22} \mathrm{Na}$ ion influx into cells was carried out as described in the legend to Figure 2. The $\left[{ }^{125} \mathrm{I}\right] \alpha$-BGT binding to cell membranes was done as described in the text. Nonspecific binding measured in the presence of $5 \mu \mathrm{M}$ unlabeled $\alpha$-BGT was corrected. Values were the means of duplicate cultures.

response by cultivating the cells in TIP/DF medium was fully recovered by the exposure of those cells to serumcontaining medium.

PC12 cells are known to have some voltage-dependent ion channels. These channels of PC12h cells cultured in TIP/DF medium still kept functioning, as shown in Figures 4 and 5. In order to open the voltage-dependent sodium channels, $0.25 \mathrm{~mm}$ veratridine was exposed to PC12h cells in the presence of $10 \mu \mathrm{g} / \mathrm{ml}$ of scorpion toxin. For opening the voltage-dependent calcium channels, the potassium concentration in assay medium was raised to $51.4 \mathrm{mM}$. As can be seen in Figure 4, both ion channels persisted in PC12h cells cultured in TIP/DF medium as well as those cultured in the serum-containing medium. Furthermore, Figure 5 shows that PC12h cells cultured in TIP/DF medium have a voltage- and calcium-

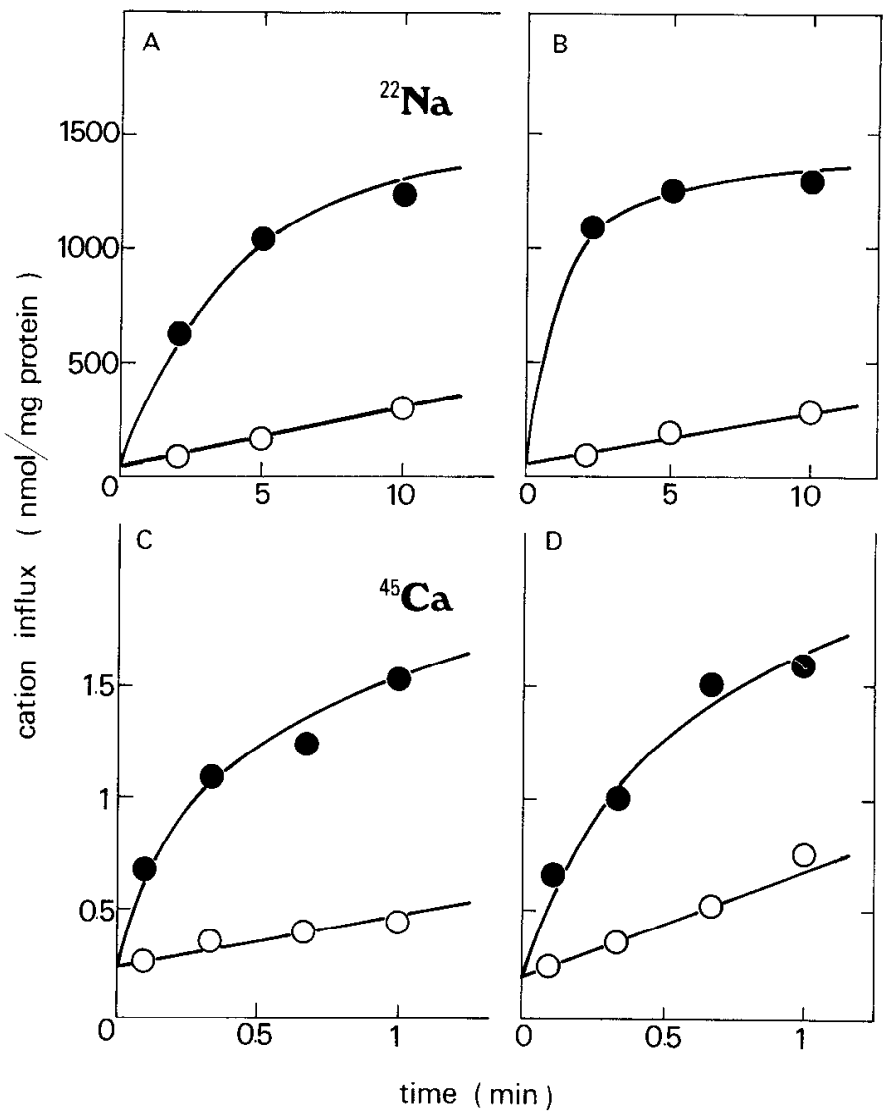

Figure 4. Voltage-dependent ${ }^{22} \mathrm{Na}$ and ${ }^{45} \mathrm{Ca}$ ion influx into PC12h cells cultured in serum-containing ( $A$ and $C$ ) and TIP/ DF ( $B$ and $D$ ) media for 3 days. Voltage-dependent sodium channels were activated by adding $0.25 \mathrm{~mm}$ veratridine $(\mathbf{O})$. Voltage-dependent calcium channels were activated by raising $\mathrm{KCl}$ concentration to $51.4 \mathrm{~mm}(\mathbf{O})$. Nonspecific ${ }^{22} \mathrm{Na}$ and ${ }^{45} \mathrm{Ca}$ ion influx into PC12h cells was also shown (O).

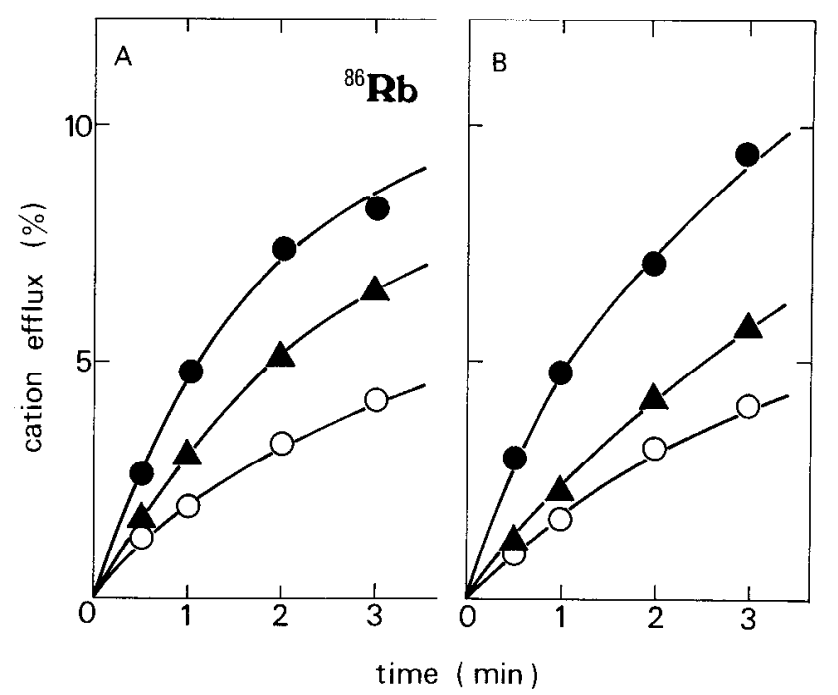

Figure $5 .{ }^{86} \mathrm{Rb}$ ion efflux from $\mathrm{PC} 12 \mathrm{~h}$ cells cultured in serumcontaining $(A)$ and TIP/DF $(B)$ media for 3 days. The preloaded ${ }^{86} \mathrm{Rb}$ ions were released from the cells in the presence of 5.4 $\mathrm{mM} \mathrm{KCl} \mathrm{(O)} \mathrm{or} 51.4 \mathrm{mM} \mathrm{KCl}(\bigcirc)$. Voltage-dependent ${ }^{86} \mathrm{Rb}$ efflux was distinguished from Ca-dependent efflux in the presence of $2 \mathrm{mM} \mathrm{MnCl}_{2}(\mathbf{\Delta})$. 
dependent potassium channel, also. The voltage- and calcium-dependent potassium channel was identified by measuring the release of the preloaded ${ }^{86} \mathrm{Rb}$ ion from the cells in response to $51.4 \mathrm{mM} \mathrm{KCl}$. The addition of $2 \mathrm{mM}$ $\mathrm{MnCl}_{2}$ distinguished the voltage-dependent potassium channel from the calcium-dependent one.

\section{Discussion}

The PC12 cell is a clonal cell line from rat pheochromocytoma and has many properties similar to those of adrenal chromaffin cells and sympathetic nerve cells (Greene and Shooter, 1980). The PC12 cell can extend neurites in response to nerve growth factor and can release the catecholamine synthesized in itself by the stimulation of ACh. In a previous paper (Hatanaka, 1981), a newly isolated cell line, PC12h, was observed as responding to nerve growth factor with the increase of tyrosine hydroxylase concomitant with choline acetyltransferase activities. However, by cultivating in serumfree medium, PC12h cells respond selectively to nerve growth factor with an increase of the former but not the latter enzyme activity (Hatanaka et al., 1982; Hatanaka, 1983). In the present study, we reported that one of the principal properties of this cell line, the function of nicotinic ACh receptor, diminished dramatically when cells were cultured in a hormone-supplemented serumfree medium, namely TIP/DF medium. Many other inherent functions of $\mathrm{PC} 12 \mathrm{~h}$ cells were comparatively maintained whether in TIP/DF or serum-containing medium. These results suggest that an unknown substance(s) contained in the serum specifically regulates the appearance of ACh sensitivity.

It cannot be determined from our results whether the decline of ${ }^{22} \mathrm{Na}$ ion influx is directly related to the reduction of nicotinic receptor molecules itself. But the slow and monoexponential decline of the function shown in Figure 3 makes us imagine that insertion of newly synthesized receptor molecules into cell membranes is stopped in TIP/DF medium, and the decline rate reflects the degradation of receptor molecules in the cell membranes. The half-life of this receptor is about 1 day, if the hypothesis mentioned above is correct. This value is identical with that described for nicotinic ACh receptors by Devreotes and Fambrough (1975) in chick skeletal muscle in culture and is very similar to that generally observed for extrajunctional mammalian muscular receptors (Merlie et al., 1976).

On the basis of this consideration, the results in this report suggest that $\mathrm{PC} 12 \mathrm{~h}$ cells in TIP/DF medium seem to be a useful model for comparing differences between $\mathrm{ACh}$ sensitivity and other functions on $\mathrm{PC} 12 \mathrm{~h}$ cells. First, it could be used to consider the relationship between nicotinic ACh receptors and $\alpha$-BGT-binding sites. $\alpha$-BGT, an elapid venom from Bungarus multicinctus, has been used and shown to block the function of skeletal muscle and electric fish nicotinic ACh receptors by binding to the cholinergic ligand recognition sites of the receptor protein (Heidmann and Changeux, 1978). Binding sites for $\alpha$-BGT of nicotinic specificity are also widely distributed in the peripheral and central nervous systems of both vertebrates and invertebrates (Morley et al.,
1979). However, the nature of these $\alpha$-BGT-binding sites remains unresolved, although they are often referred to as putative neuronal nicotinic receptors. Patrick and Stallcup (1977) first reported that detergent-solubilized $\alpha$-BGT-binding sites were distinct from functional nicotinic $\mathrm{ACh}$ receptors immunologically, by using PC12 cells; but the possibility that functional receptor molecules and $\alpha$-BGT-binding site have some linkage on intact cell membranes could not be discarded. The results shown in Figure 3 indicate that the appearance of carbamylcholine sensitivity and $\alpha$-BGT-binding sites was controlled by different mechanisms, suggesting that there is no linkage of existence between these two molecules in the intact cell membranes. PC12 cells are known to have responsibility to nerve growth factor as well as epidermal growth factor (Greene and Tischler, 1976; Guroff et al., 1981). We also investigated the effect of these factors on $\mathrm{ACh}$ sensitivity and $\alpha$-BG'I binding, showing that both factors obviously increased the former but not the latter (M. Mitsuka and H. Hatanaka, manuscript in preparation). These data also support the above considerations.

Second, it could be used to make more clear the relationship between the ion channel(s) coupled to nicotinic $\mathrm{ACh}$ receptors and channels which have voltage sensitivity. It has been considered that PC12 cells have both voltage-dependent and receptor-coupled ion channels (Stallcup, 1979). But the difference between these channels has been confirmed only by pharmacological evidence, and the properties and the relationship of these channels were not understood in detail. The results in this report indicate that the appearance of voltage- and receptor-coupled ion channels was regulated by different mechanisms. It confirms the nature of the idea that the molecules bearing the functions of receptor-coupled and voltage-dependent ion channels are distinct.

It is very interesting to make clear the substance(s) and mechanism(s) which regulate the appearance of the function of the nicotinic ACh receptor. We have also confirmed that albumin or its complexes in the serum has an important role in the appearance of the functions of the receptors, and detailed results will be reported elsewhere. PC12h cells in TIP/DF medium lack only the function of nicotinic receptor as far as has been examined; thus it seems to be a very useful model for studying the differentiating mechanism of neuronal nicotinic ACh receptors. Further experiments to explain this mechanism are expected.

\section{References}

Arner, L. S., and W. B. Stallcup (1981) Two types of potassium channels in the PC12 cell line. Brain Res. 215: 419-425.

Barnes, D., and G. Sato (1980) Serum-free cell culture: A unifying approach. Cell 22: 649-655.

Bocchini, V., and P. V. Angeletti (1969) The nerve growth factor: Purification as a 30,000-molecular weight protein. Proc. Natl. Acad. Sci. U. S. A. 64: 787-794.

Bottenstein, J. E., and G. H. Sato (1979) Growth of a rat neuroblastoma cell line in serum-free supplemented medium. Proc. Natl. Acad. Sci. U. S. A. 76: 514-517.

Darmon, M., J. E. Bottenstein, and G. Sato (1981) Neuronal differentiation following culture of embryonal carcinoma 
cells in a serum-free defined medium. Dev. Biol. 85: 463-473.

Devreotes, P., and D. H. Fambrough (1975) Acetylcholine receptor turnover in membranes of developing muscle fibers. J. Cell Biol. 65: 335-358.

Greene, L. A., and G. Rein (1977) Release of $\left[{ }^{3} \mathrm{H}\right]$ norepinephrine from a clonal line of pheochromocytoma cells (PC12) by nicotinic cholinergic stimulation. Brain Res. 138: 521-528.

Greene, L. A., and E. M. Shooter (1980) The nerve growth factor: Biochemistry, synthesis, and mechanism of action. Annu. Rev. Neurosci. 3: 353-402.

Greene, L. A., and A. S. Tischler (1976) Establishment of a noradrenergic clonal line of rat adrenal pheochromocytoma cells which respond to nerve growth factor. Proc. Natl. Acad. Sci. U. S. A. 73: 2424-2428.

Guroff, G., G. Dickens, and D. End (1981) The induction of ornithine decarboxylase by nerve growth factor and epidermal growth factor in PC12 cells. J. Neurochem. 37: 342-349.

Hatanaka, H. (1981) Nerve growth factor-mediated stimulation of tyrosine hydroxylase activity in a clonal rat pheochromocytoma cell line. Brain Res. 222: 225-233.

Hatanaka, H. (1983) Nerve growth factor-mediated differentiation of a nerve cell line cultured in a hormone-supplemented serum-free medium. Dev. Brain Res. 6: 243-250.

Hatanaka, H., M. Takahashi, and M. Mitsuka (1982) Novel nerve growth factor-responsiveness of catecholamine biosynthesis and secretion in clonal rat pheochromocytoma cells cultured in a hormone-supplemented serum-free medium. Adv. Biosci. 36: 111-118.

Heidmann, T., and J. P. Changeux (1978) Structural and functional properties of the acetylcholine receptor protein in its purified and membrane-bound states. Annu. Rev. Biochem. 47: 317-357.

Hunter, W. M., and F. C. Greenwood (1962) Preparation of iodine-131 labeled human growth hormone of high specific activity. Nature 194: 495-496.

Inoue, N., and H. Hatanaka (1982) Nerve growth factor induces specific enkephalin binding sites in a nerve cell line. J. Biol. Chem. 257: 92389241.

Jumblatt, J. E., and A. S. Tischler (1982) Regulation of muscarinic ligand binding sites by nerve growth factor in PC12 phaeochromocytoma cells. Nature 297: 152-154.

Lowry, O. H., N. J. Rosebrough, A. L. Farr, and R. J. Randall (1951) Protein measurement with the Folin phenol reagent. J. Biol. Chem. 193: 262-275.

Merlie, J., J. P. Changeux, and F. Gros (1976) Acetylcholine receptor degradation measured by pulse chase labelling. $\mathrm{Na}$ ture 264: 74-76.

Messer, A. (1981) Primary monolayer cultures of the rat corpus striatum: Morphology and properties related to acetylcholine and $\gamma$-aminobutyrate. Neuroscience $6: 2677-2687$.

Morley, B. J., G. E. Kemp, and P. Salvaterra (1979) $\alpha$-Bungarotoxin binding sites in the CNS. Life Sci. 24: 859-872.

Patrick, J., and W. B. Stallcup (1977) $\alpha$-Bungarotoxin binding and cholinergic receptor function on a rat sympathetic nerve line. J. Biol. Chem. 252: 8629-8633.

Seto, A., Y. Arimatsu, and T. Amano (1977) A glycoprotein resembling peripheral nicotinic acetylcholine receptor that binds $\left[{ }^{125} \mathrm{I}\right] \alpha$-bungarotoxin in mouse brain. Neurosci. Lett. 4 : 115-119.

Stallcup, W. B. (1979) Sodium and calcium fluxes in a clonal nerve cell line. J. Physiol. (Lond.) 286: 525-540.

Suda, K., Y. A. Barde, and H. Thoenen (1978) Nerve growth factor in mouse and rat serum: Correlation between bioassay and radioimmunoassay determinations. Proc. Natl. Acad. Sci. U. S. A. 75: 4642-4646.

Takahashi, M., Y. Ohizumi, and T. Yasumoto (1982) Maitotoxin, a $\mathrm{Ca}^{++}$channel activator candidate. J. Biol. Chem. 257: $7287-7289$. 